\title{
Novel Mechanism for Surface Layer Shedding and Regenerating in Bacteria Exposed to Metal-Contaminated Conditions
}

\author{
Archjana Chandramohan ${ }^{1}$, Elodie Duprat ${ }^{2}$, Laurent Remusat $^{2}$, Severine Zirah ${ }^{1}$, \\ Carine Lombard ${ }^{1}$ and Adrienne Kish ${ }^{1 *}$
}

${ }^{1}$ Unité Molécules de Communication et Adaptation des Microorganismes (MCAM), Muséum National d'Histoire Naturelle, CNRS UMR 7245, Paris, France, ${ }^{2}$ Institut de Minéralogie, Physique des Matériaux et de Cosmochimie (IMPMC), Sorbonne Université, Muséum National d'Histoire Naturelle, CNRS UMR 7590, IRD UMR 206, Paris, France

\section{OPEN ACCESS}

Edited by:

Stéphane Pesce,

National Research Institute of Science and Technology for Environment and Agriculture (IRSTEA), France

Reviewed by:

Mariusz Cycoń

Medical University of Silesia, Poland

Sukhendu Mandal,

University of Calcutta, India

*Correspondence: Adrienne Kish

adrienne.kish@mnhn.fr

Specialty section:

This article was submitted to Microbiotechnology, Ecotoxicology

and Bioremediation,

a section of the journal

Frontiers in Microbiology

Received: 13 September 2018 Accepted: 11 December 2018

Published: 15 January 2019

Citation:

Chandramohan A, Duprat E,

Remusat L, Zirah S, Lombard C and

Kish A (2019) Novel Mechanism

for Surface Layer Shedding

and Regenerating in Bacteria

Exposed to Metal-Contaminated

Conditions. Front. Microbiol. 9:3210.

doi: 10.3389/fmicb.2018.03210
Surface layers (S-layers) are components of the cell walls throughout the Bacteria and the Archaea that provide protection for microorganisms against diverse environmental stresses, including metal stress. We have previously characterized the process by which S-layers serve as a nucleation site for metal mineralization in an archaeon for which the S-layer represents the only cell wall component. Here, we test the hypothesis originally proposed in cyanobacteria that a "shedding" mechanism exists for replacing S-layers that have become mineral-encrusted, using Lysinibacillus sp. Tchlll 20n38, metallotolerant gram-positive bacterium, as a model organism. We characterize for the first time a mechanism for resistance to metals through S-layer shedding and regeneration. S-layers nucleate the formation of Fe-mineral on the cell surface, depending on physiological state of the cells and metal exposure times, leading to the encrustation of the S-layer and changes in the cell morphology as observed by scanning electron microscopy. Using Nanoscale Secondary lon Mass Spectrometry, we show that mineral-encrusted S-layers are shed by the bacterial cells after a period of latency (2 days under the conditions tested) in a heterogeneous fashion likely reflecting natural variations in metal stress resistance. The emerging cells regenerate new S-layers as part of their cell wall structure. Given the wide diversity of S-layer bearing prokaryotes, S-layer shedding may represent an important mechanism for microbial survival in metal-contaminated environments.

\section{Keywords: S-layer, metal, biomineralization, metallotolerance, Lysinibacillus}

\section{INTRODUCTION}

Environmental contamination by metals and radionuclides from activities such as mining and nuclear power generation pose a serious risk to human health. The sudden, accidental release of high concentrations of iron from acid mine drainage from the Gold King Mine polluted the Animas River in 2015, mixing downstream with phosphates from agricultural runoff (Rodriguez-Freire et al., 2016). Metal contamination affected both water supplies from soluble metals, and sediments after the sedimentation of the majority of released metals. Sampling of soils contaminated by metals 
and radionuclides near the former Chernobyl nuclear reactor site (Chapon et al., 2012) and in uranium mining waste piles in Germany (Pollmann et al., 2006) have identified bacteria of the genre Lysinibacillus tolerant to these contaminants. Lysinibacillus [formerly classified as part of the Bacillus genre (Ahmed et al., 2007)] gram-positive bacteria, with a peptidoglycan cell wall enclosed by a surface layer ("S-layer") attached non-covalently to the lipopolysaccharides of the outer membrane (reviewed in Sleytr et al., 2014). These S-layers have proven to be a key mechanism for metallotolerance in Lysinibacillus as they have been shown to bind U, Pd(II), Cu, Pt(II), and Au(III) (Pollmann et al., 2006).

S-Layers, however are not unique to Lysinibacillus. They are common components of the cell envelopes of both bacteria and archaea. S-layers are formed by self-assembly of repeated protein monomers into ordered structures (oblique, square, or hexagonal) depending on the number of subunits composing the ordered structure. This self-assembly occurs even in the absence of cells in vitro; a capacity has been exploited in biotechnology in everything from the development of vaccine to nanomaterials to filtration technologies (Sleytr et al., 2011).

S-Layers form the interaction interface between prokaryotic cells and their external environment, and are therefore in contact with metals and other ions present. Nucleation of mineralization by S-layers was first noted in cyanobacteria by Schultze-Lam et al. (1992). Cyanobacterial S-layers were demonstrated to nucleate the formation of carbonates of calcium, magnesium, and strontium (Schultze-Lam and Beveridge, 1994). SchultzeLam et al. (1992) proposed the hypothesis that mineral-encrusted S-layers are shed from cyanobacteria as part of a protective mechanism to ensure that essential cell activities are maintained despite cell wall mineralization. This hypothesis was, however, never fully tested. Since then, S-layer nucleation of mineralization has been observed in a range of bacteria (Konhauser et al., 1994; Phoenix et al., 2000) and archaea (Kish et al., 2016).

Here, we describe the shedding and regeneration of mineralencrusted S-layers in the metallotolerant environmental isolate Lysinibacillus sp. TchIII 20n38.

\section{MATERIALS AND METHODS}

\section{Culture and Growth Conditions}

The bacterial strain used was an environmental strain isolated in 2009 from soils near a radionuclide-contaminated site (Chapon et al., 2012). This strain, referenced as Lysinibacillus sp. TchIII 20n38, was cultured at $30^{\circ} \mathrm{C}$ in Luria Bertani (LB) medium under aerobic conditions with agitation $(180 \mathrm{rpm})$ to mid-exponential, late-exponential, and stationary growth phases $\left(\mathrm{OD}_{600 \mathrm{~nm}}=0.3\right.$, 0.6 , and 1.0 , respectively). The culture medium was then removed and the cells washed in MilliQ- $\mathrm{H}_{2} \mathrm{O}$ by gentle centrifugation $(2600 \times g, 15 \mathrm{~min}$, room temperature). In order to determine the mechanisms of resistance of Lysinibacillus sp. TchIII 20n38 cells to the presence of heavy metals, the cells were resuspended to an equivalent cell density in a Fe-rich solution at a similar $\mathrm{pH}$ to that found in the Chernobyl isolation $\left(10 \mathrm{mM} \mathrm{NaH}{ }_{2} \mathrm{PO}_{4}\right.$, $\left.10 \mathrm{mM} \mathrm{FeSO}_{4}, \mathrm{pH}=4.5\right)$, and agitated $\left(150 \mathrm{rpm}, 30^{\circ} \mathrm{C}\right)$ with for up to 5 days. Cells were filtered and observed by scanning electron microscopy (SEM) as described below.

\section{Mineralization Recovery Time Course}

In order to test the hypothesis that mineral-encrusted S-layers are shed and regenerated, a time course of recovery was followed after Fe-mineralization as follows: Lysinibacillus sp. TchIII 20 n 38 cells were grown to mid-exponential growth phase $\left(\mathrm{OD}_{600 \mathrm{~nm}}=0.3\right)$ in $\mathrm{LB}\left(30^{\circ} \mathrm{C}, 180 \mathrm{rpm}\right)$. The culture medium was then removed and the cells washed in MilliQ- $\mathrm{H}_{2} \mathrm{O}$ by gentle centrifugation $(2600 \times g, 15 \mathrm{~min}$, room temperature). The cells were then resuspended to an equivalent cell density in either a mineralization solution $\left(10 \mathrm{mM} \mathrm{NaH} \mathrm{PO}_{4}, 10 \mathrm{mM} \mathrm{FeSO}_{4}\right.$, $\mathrm{pH}=4.5)$, or a nutrient-free buffered solution at the same $\mathrm{pH}$ $\left(10 \mathrm{mM} \mathrm{NaH} \mathrm{PO}_{4}, \mathrm{pH}=4.5\right)$, and agitated $\left(30^{\circ} \mathrm{C}, 150 \mathrm{rpm}\right)$ for $16 \mathrm{~h}$. The mineralization solution was then removed and the cells washed in MilliQ- $\mathrm{H}_{2} \mathrm{O}$ by gentle centrifugation $(2600 \times g$, $15 \mathrm{~min}$, room temperature), and replaced by growth medium (LB, or labeled growth medium).

For nanoscale secondary ion mass spectrometry (NanoSIMS) experiments, LB was replaced with a defined growth medium approximating LB but containing either ${ }^{14} \mathrm{~N}$ or ${ }^{15} \mathrm{~N}$ (Celtone ${ }^{\circledR}$, Cambridge Isotopes, United States). While specified for use with bacteria for isotope analyses, this media was found to contain inhibitory concentrations of trace metals, which we were able to remove by precipitation by addition of an excess of buffered phosphate $(10 \mathrm{mM})$ over $24 \mathrm{~h}$ with agitation at $150 \mathrm{rpm}$, followed by filtration using a $0.22 \mu \mathrm{m}$ filter. This metal-depleted medium containing $5 \mathrm{~g} / \mathrm{L}$ Celtone ${ }^{\circledR}$ was completed with $5 \mathrm{~g} / \mathrm{L}$ acetate as a C-source, and basal salts (15 mM ammonium sulfate, $0.2 \mathrm{mM}$ $\mathrm{MgSO}_{4}, 17.6 \mathrm{mM} \mathrm{KH}_{2} \mathrm{PO}_{4}, 32.7 \mathrm{mM} \mathrm{NaH}_{2} \mathrm{PO}_{4}$ ), as determined by our preliminary optimized experiments with Lysinibacillus sp. TchIII 20n38. In addition, cultures grown in the presence of ${ }^{14} \mathrm{~N}$ rather than ${ }^{15} \mathrm{~N}$ rapidly ceased vegetative growth and sporulated. Therefore instead of a standard labeling medium composed of both ${ }^{14} \mathrm{~N}$ and ${ }^{15} \mathrm{~N}$, a $100 \%{ }^{15} \mathrm{~N}$-labeled medium, was used to follow the time course of recovery after Fe-exposure. An additional culture was resuspended in a $100 \%{ }^{14} \mathrm{~N}$ medium and immediately sampled as a baseline control for $\mathrm{N}$ isotope abundances. Cultures were incubated in the ${ }^{15} \mathrm{~N}$-labeled medium at $30^{\circ} \mathrm{C}$ with agitation $(180 \mathrm{rpm})$ over a time course of recovery, for both mineralized (M) and non-mineralized (NM) cultures. Aliquots were removed immediately after addition of growth medium (T0), and then every $24 \mathrm{~h}$ (1, 2 days). At each time point, approximately $20 \mathrm{~mL}$ aliquots were removed for optical density measurements, optical microscopy verification of cell morphology, and filtered for SEM observations and NanoSIMS analyses as described below. Abiotic (non-inoculated) controls were used for comparison to distinguish mineralization due to the presence of Lysinibacillus sp. TchIII 20 n38 cells.

\section{Scanning Electron Microscopy}

Aliquots of bacterial cultures as well as abiotic controls (not inoculated with Lysinibacillus sp. TchIII 20n38 cells) were filtered through a $0.2 \mu \mathrm{m}$ GTTP isopore polycarbonate filters using a Swinnex filter holder (Merck Millipore, Darmstadt, Germany). Filters were then air-dried, mounted on aluminum supports 
with carbon tape, and coated with carbon (7-8 nm thickness), gold (7 $\mathrm{nm}$ thickness), or platinum (5 $\mathrm{nm}$ thickness). SEM observations were performed using two different instruments; a Hitachi SU 3500 SEM installed at the electron microscopy platform of the Muséum National d'Histoire Naturelle (Paris, France), and a Zeiss Ultra 55 field emission gun SEM equipped with a Brucker EDS QUANTAX detector (Brucker Corporation, Houston, TX, United States) installed at IMPMC (Sorbonne Université, Paris, France). For observations using the Hitachi SU 3500 instrument observations were made in secondary electron mode with an acceleration voltage of $15 \mathrm{kV}$. SEM-FEG images were acquired in secondary electron mode using with the Zeiss Ultra 55 instrument with an in column detector (InLens) at 2 to $5 \mathrm{kV}$ and a working distance of $3 \mathrm{~mm}$. Energy dispersive $\mathrm{X}$-ray spectroscopy (EDX) analyses were performed at $15 \mathrm{kV}$ and a working distance of $7.5 \mathrm{~mm}$ after calibration with reference copper.

\section{Nano Secondary Ion Mass Spectrometry}

Nano secondary ion mass spectrometry sample preparations followed the protocol of Miot et al. (2015). Briefly, aliquots of bacterial cultures sampled from labeled and unlabeled media filtered through $0.2 \mu \mathrm{m}$ GTTP isopore polycarbonate filters previously Au-coated (20 nm thickness) using a Swinnex filter holder (Merck Millipore, Darmstadt, Germany). Quantitative ion images were recorded by the NanoSIMS50 (Cameca, Gennevilliers, France) installed at the National Museum of Natural History of Paris, France. All measurements were performed using the same analytical conditions. A Cs + primary beam of $0.8 \mathrm{pA}$ scanned an area of $20 \mu \mathrm{m} \times 20 \mu \mathrm{m}$, divided into 256 pixels $\times 256$ pixels, with a counting time of $1 \mathrm{~ms}$ per pixel. Secondary ion images of ${ }^{31} \mathrm{P}^{16} \mathrm{O}-,{ }^{12} \mathrm{C}^{14} \mathrm{~N}$-, and ${ }^{12} \mathrm{C}^{15} \mathrm{~N}$ were recorded. The mass resolution power was adjusted to 9000 to resolve isobaric interferences at mass 27 such as ${ }^{13} \mathrm{C}^{14} \mathrm{~N}$ - or ${ }^{11} \mathrm{~B}^{16} \mathrm{O}$ from ${ }^{12} \mathrm{C}^{15} \mathrm{~N}$-. Before any analysis, the surface of each sample was pre-sputtered during $5 \mathrm{~min}$ with a $80 \mathrm{pA}$ Cs- primary ion beam over $30 \mu \mathrm{m} \times 30 \mu \mathrm{m}$ to eliminate the contamination of the surface, and reached the stable state of sputtering (Thomen et al., 2014). Instrument stability was verified throughout the session using a type 3 kerogen standard. NanoSIMS data were then processed using the IMAGE software (L. Nittler, Carnegie Institution for Science, Washington, DC, United States).

\section{Statistical Analyses}

The preference of this strain of Lysinibacillus for ${ }^{15} \mathrm{~N}$ to maintain vegetative growth eliminated the possibility of using a ${ }^{14} \mathrm{~N}$ control throughout the time course of recovery. In order to automatically remove the random noise from all the ${ }^{12} \mathrm{C}^{14} \mathrm{~N}$ and ${ }^{12} \mathrm{C}^{15} \mathrm{~N}$ - NanoSIMS images, we defined ${ }^{12} \mathrm{C}^{14} \mathrm{~N}$ - and ${ }^{12} \mathrm{C}^{15} \mathrm{~N}$ independent thresholds based on their respective distribution for the images of samples that were resuspended in the ${ }^{14} \mathrm{~N}$ labeled medium. Each elemental distribution was fitted by two Gaussian components (R-package mixtools, Benaglia et al., 2009). We define threshold as the mean of the 97.5th percentile of the first Gaussian component (noise) and the 2.5th percentile of the second one (signal).
For each image, the denoised dataset further used for statistical analyses is composed only of pixels with both ${ }^{12} \mathrm{C}^{14} \mathrm{~N}$ - and ${ }^{12} \mathrm{C}^{15} \mathrm{~N}$ - values above the respective thresholds. The isotope abundance ${ }^{12} \mathrm{C}^{15} \mathrm{~N}-/\left({ }^{12} \mathrm{C}^{14} \mathrm{~N}-+{ }^{12} \mathrm{C}^{15} \mathrm{~N}-\right)$ of this dataset (hereafter named processed ${ }^{15} \mathrm{~N} /\left({ }^{14} \mathrm{~N}+{ }^{15} \mathrm{~N}\right)$ ratio) was used to follow the kinetics of incorporation of $\mathrm{N}$ (as part of protein production) by non-mineralized and mineralized bacteria. For each image, the distribution of processed ${ }^{15} \mathrm{~N} /\left({ }^{14} \mathrm{~N}+{ }^{15} \mathrm{~N}\right)$ ratio was fitted using Gaussian mixture modeling (R-package mclust, Scrucca et al., 2016) in order to infer subpopulations of pixels. The best univariate model, composed of $k$ Gaussian components with either equal or unequal variance, was selected based on Bayesian Information Criterion. The mixing proportions for the components represent the proportions of the $k$ subpopulations of pixels.

Cluster analysis was performed in order to group the samples according to their subpopulation composition. Each image was described by a vector of 10 values, each corresponding to the sum of the mixing proportions for the Gaussian components whose mean falls in a given ${ }^{15} \mathrm{~N} /\left({ }^{14} \mathrm{~N}+{ }^{15} \mathrm{~N}\right)$ ratio interval (10 intervals of size 0.1 each). An image-to-image distance matrix generated by computing Bray-Curtis dissimilarity index between all the pairs of vectors was used for hierarchical agglomerative clustering of images (unweighted pair group method with arithmetic mean linkage).

All analyses were conducted in $\mathrm{R}$ version 3.2.3 ( $\mathrm{R}$ Core Team, 2015).

\section{RESULTS}

\section{Lysinibacillus sp. S-Layers Become Encrusted After Exposure to Iron}

Lysinibacillus sp. TchIII 20n38 was isolated from soils contaminated by radionuclides and metals, resulting in a moderately acidic pH (5.5) (Chapon et al., 2012). Our work with this strain, like other isolates from the same site, has shown that it is resistant to a range of heavy metals and radionuclides (data not shown). To determine the mechanisms of this metallotolerance, we exposed cells to a Fe-rich solution at acidic $\mathrm{pH}$ in the absence of the preferred carbon source for this strain, acetate, while maintaining high levels of phosphate required by Lysinibacillus sp. Nonmetabolic metal-tolerance mechanisms are favored under these conditions.

After exposure, Fe-minerals were observed to form on the surface of Lysinibacillus sp. cells leading to complete encrustation of the cells over time (see Figure 1). EDX analyses of mineralencrusted cells confirmed the composition as a Fe-phosphate (see Supplementary Figure S1). Some abiotically formed Fephosphates were also observed, which were easily distinguishable from mineralized S-layers as aggregates of larger sphericallyshaped minerals not associated with cells, and matching the types of minerals observed in non-inoculated controls.

Cells were fully mineral encrusted after $16 \mathrm{~h}$ of exposure to the Fe-rich solution, whether cells were exposed in mid-exponential, late-exponential, or stationary growth phase $\left(\mathrm{OD}_{600 \mathrm{~nm}}=0.3,0.6\right.$, 

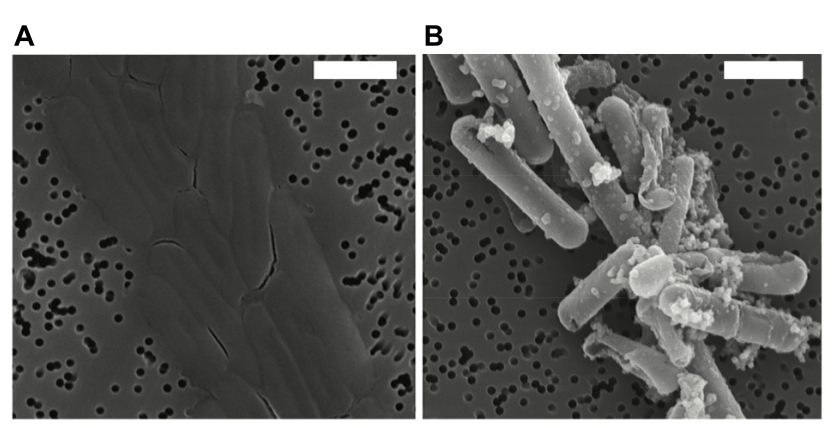

FIGURE 1 | Scanning electron microscopy (SEM) images in secondary electron mode of Lysinibacillus sp. Tchlll 20n38 cells (A) grown under optimal conditions, and (B) after exposure to an iron-rich solution (10 $\mathrm{mM} \mathrm{NaH}_{2} \mathrm{PO}_{4}$, $\left.10 \mathrm{mM} \mathrm{FeSO}_{4}, \mathrm{pH}=4.5\right)$. SEM images acquired in secondary electron mode. Scale bars are each $2 \mu \mathrm{m}$ in length.

and 1.0, respectively). Longer exposures (20 and $41 \mathrm{~h}$ ) did not alter the extent mineralization.

Attempts to confirm whether the mineralization observed on Lysinibacillus sp. TchIII 20n38 cells was due to a completely non-metabolic process, or whether active metabolism by living cells was necessary for S-layer mineralization were limited due to an inability to obtain dead cells without damaging the S-layer containing cell envelope. This despite multiple trials employing various antibiotics targeting non-cell envelope structures, and testing them over a large range of concentrations and durations [tetracycline (10-2000 $\mu \mathrm{g} / \mathrm{mL}$ for $1 \mathrm{~h}-5$ days in LB, buffer, or MilliQ- $\mathrm{H}_{2} \mathrm{O}$ ) ofloxacin (10-500 $\mu \mathrm{g} / \mathrm{mL}$ ), and heat treatments (up to $\left.55^{\circ} \mathrm{C}\right)$ ]. The fact that Lysinibacillus sp. TchIII $20 \mathrm{n} 38$ cells grow optimally as heterotrophs without added metals suggests that the role of any metabolic processes in S-layer mineralization was secondary to non-metabolic processes.

\section{Response to Metal Exposure Depends on Physiological State, Times of Mineralization and Recovery}

Replacement of mineral-encrusted cells into a rich growth medium demonstrated that Lysinibacillus sp. TchIII 20 n 38 cells were able to resume proper cell division after complete Femineral encrustation. The exposure of mid-exponential growth phase cells $\left(\mathrm{OD}_{600 \mathrm{~nm}}=0.3\right)$ to the Fe-rich solution for $16 \mathrm{~h}$ followed by recovery of the cultures in LB showed that cells resumed normal cell division (see Supplementary Figure S2). However, the physiological state of the cells during metal exposure affected the ability of cells to recover after mineral encrustation, resulting in various inhibitions of normal vegetative cell growth and division. For mid-exponential growth phase cells, exposures longer than $16 \mathrm{~h}$ to the Fe-rich solution resulted in the death of mineralized cells, and the formation of filaments by the small minority of cells observed without mineral-encrustation. In the case of both late-exponential growth phase and stationary phase cultures, even $16 \mathrm{~h}$-long exposures to Fe resulted in sporulation and/or cell death.

\section{Mineral-Encrusted S-Layers Can Be Shed}

Scanning electron microscopy observations were made of midexponential growth phase Lysinibacillus sp. TchIII $20 \mathrm{n} 38$ cells after a $16 \mathrm{~h}$ exposure to the Fe-rich solution. Mineralized S-layers devoid of a cell were observed, often with the cells located beside these empty mineralized S-layer shell (see Figure 2A, left and right images). After incubation in LB for up to 5 days following Fe-mineralization, cells were seen exiting mineralized S-layer cells, with cell division septa visible (see Figure 2B, top and bottom images), in concordance with increases in the optical density of the cultures (see Supplementary Figure S2).

\section{Lysinibacillus sp. Cell Morphology Changes During S-Layer Shedding}

The cell morphology in both mineralized and non-mineralized cultures was altered over the time course of recovery (see Figure 3). In non-mineralized cultures which were kept at the same $\mathrm{pH}$ as the mineralized cultures but in the absence of iron, cells gradually shrank in size and became ovoid in shape over 2 days of incubation in the metal-depleted Celtone ${ }^{\circledR}$ medium. While cell death was minimal for non-mineralized cells, dead cells were easily distinguishable due to both their high ${ }^{12} \mathrm{C}^{14} \mathrm{~N}^{-}$ counts due to lack of ${ }^{15} \mathrm{~N}$ incorporation, and their sustained rod shape (see image of non-mineralized cells 1 day in Figure 4). Non-mineralized cells also formed intracellular polyphosphate granules between 1 and 2 days of incubation, as evidenced by analyses of ${ }^{31} \mathrm{P}^{16} \mathrm{O}$ - counts (see Figure 4).

Mineralized cultures showed little change over the first day of incubation. On the second day, however, cells were observed outside of their mineralized S-layer shells, with biofilm formation evidenced as a mucoid phenotype (see Figure 3) together with increases in optical density of the cultures (see Supplementary Figure S3). SDS-PAGE and mass spectrometry confirmed the presence of S-layer glycoproteins throughout the time course of recovery (see Supplementary Figures S4, S5, and Supplementary Tables S1-S4). Shed, mineralized S-layers maintained the elongated rod shape of non-stressed Lysinibacillus sp. TchIII 20n38 cells and restricted ${ }^{31} \mathrm{P}^{16} \mathrm{O}$ - to their surfaces (see Figure 4), likely within the Fe-phosphate minerals analyzed by EDX in Figure 2. In comparison, newly emerged cells lacked surface phosphates, some cells concentrating phosphate as intracellular granules (see Figure 4). On the third day of incubation, cells in both mineralized and non-mineralized cultures began to sporulate.

\section{Sub-Populations of Cells Co-exist During Time Course of Recovery}

In order to describe the process of S-layer regeneration after mineral encrustation, and to determine if the S-layers were indeed regenerated, we followed the recovery of Lysinibacillus sp. TchIII 20n38 cells over time after Fe-mineral encrustation. Both SEM observations of cell morphology and NanoSIMS analyses of cell activity using incorporation of nitrogen, needed for the production of new S-layer proteins. ${ }^{15} \mathrm{~N}$-incorporation 

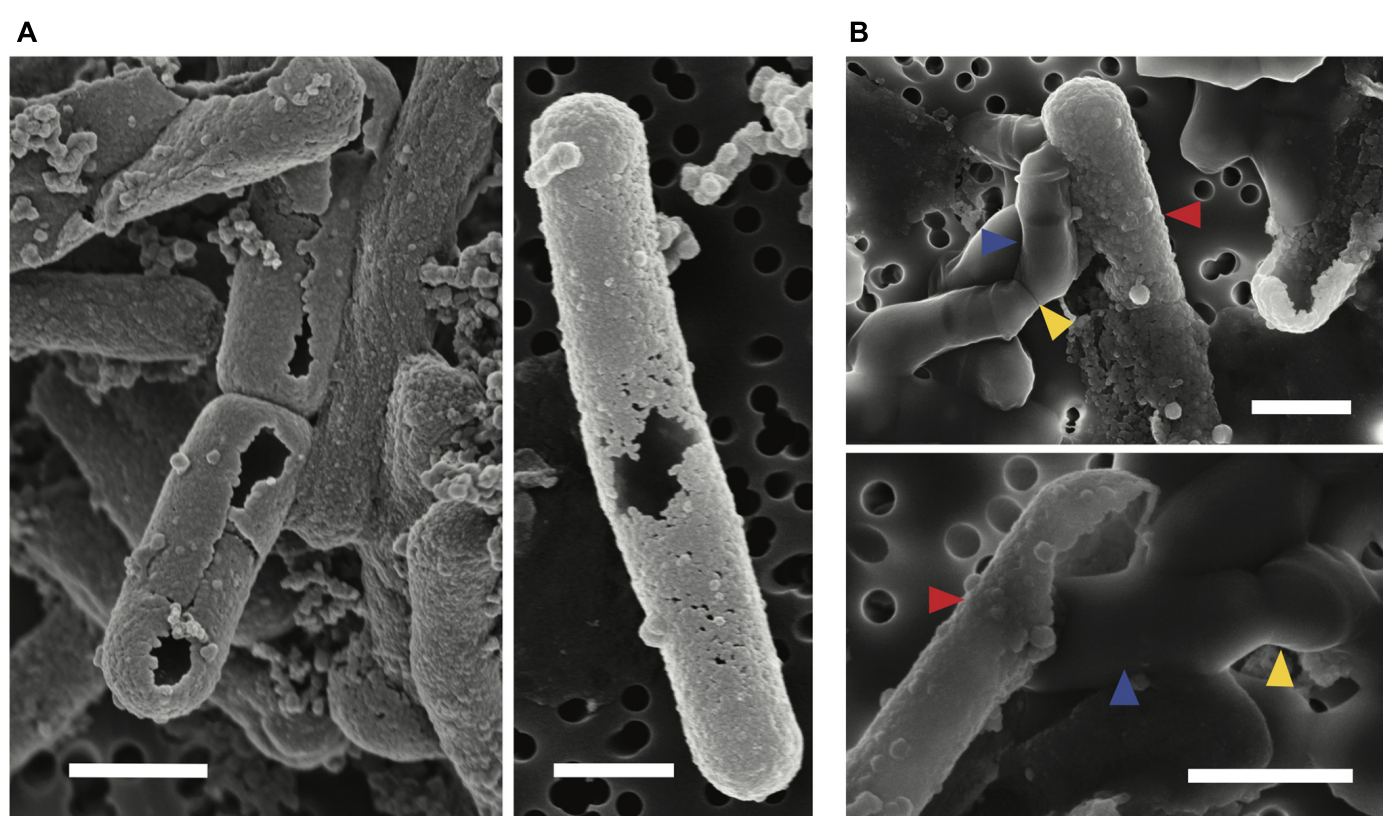

FIGURE 2 | S-layer mineralization after exposure to Fe as observed by SEM in secondary electron mode. (A) Empty mineralized S-layer "shell" lacking a cell observed by SEM (secondary electron mode) after a $16 \mathrm{~h}$ exposure of a mid-exponential growth phase culture of Lysinibacillus sp. Tchlll 20 n38 to the Fe-rich solution. Empty S-layer mineral encrustation can be thick (lift-side image) or thinner and "lacy" (right-side image). (B) Top and bottom images show cells emerging from shed mineralized S-layers. Cells were in mid-exponential growth phase prior to exposed to Fe, followed by incubated in LB for up to 5 days ( $37^{\circ} \mathrm{C}$, 180 rpm). Blue arrows show emerging cells. Red arrows indicate mineralized S-layers. Yellow arrows indicate cell division septa. Scale bars for all images are $1 \mu \mathrm{m}$ in length.

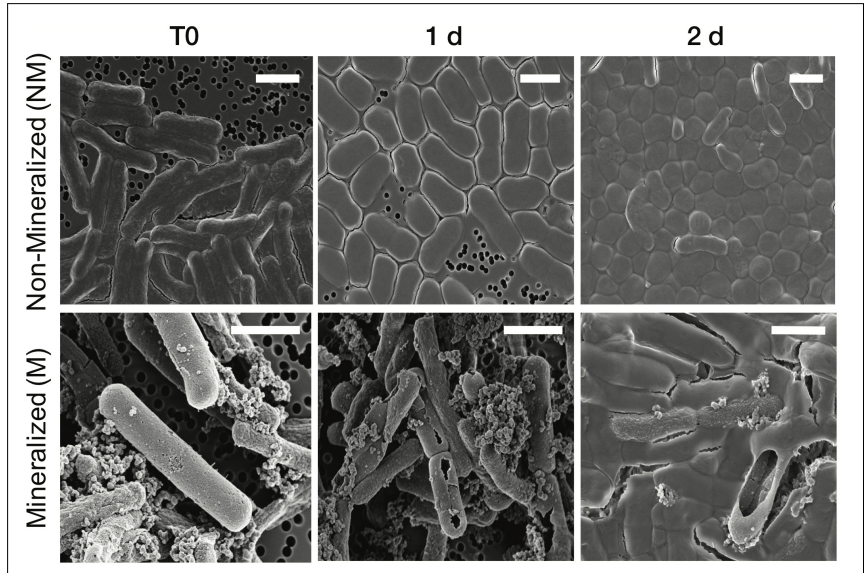

FIGURE 3 | Scanning electron microscopy images of Lysinibacillus sp. Tchlll $20 n 38$ cells (secondary electron mode) for mineralized and non-mineralized cells over a time course of recovery after Fe-exposure. Scale bars are each $2 \mu \mathrm{m}$ in length.

is an effective marker, as S-layer proteins are one of the most abundant cellular proteins, and roughly $20 \%$ of total protein synthesis can be dedicated to their production (Sleytr et al., 2007). The ${ }^{15} \mathrm{~N}$ incorporation over time was determined using ${ }^{12} \mathrm{C}^{15} \mathrm{~N} /\left({ }^{12} \mathrm{C}^{15} \mathrm{~N}+{ }^{12} \mathrm{C}^{14} \mathrm{~N}\right)$ and statistical analyses of the ${ }^{15} \mathrm{~N} /\left({ }^{14} \mathrm{~N}+{ }^{15} \mathrm{~N}\right)$ were then performed (see example of sample M_T0_rep2 in Figure 5 and Supplementary Figure S6). In order to account for differences in cell morphology over time and between mineralized and non-mineralized samples, statistical analyses were performed using all pixels above the established threshold from each image. At least three processed ${ }^{15} \mathrm{~N} /\left({ }^{14} \mathrm{~N}+\right.$ ${ }^{15} \mathrm{~N}$ ) images were analyzed per sample time point for samples incubated in medium containing ${ }^{15} \mathrm{~N}$ (two images each for natural abundance controls), with 10 to $<60$ cells per image depending on the physiological state of the cells over the time course. Subpopulations of pixels were identified for each sample according to the distribution of processed ${ }^{15} \mathrm{~N} /\left({ }^{14} \mathrm{~N}+{ }^{15} \mathrm{~N}\right)$ ratio (see Figure 5). Figure 5 shows that at the start of the time course (T0), the mineralized cells had ${ }^{15} \mathrm{~N} /\left({ }^{14} \mathrm{~N}+{ }^{15} \mathrm{~N}\right)$ ratios below 0.5 (panel A), with most cells having a ratio near 0.3 (panel B). Pixel subpopulations clustered around cells (panel C), with most mineralized cells and abiotic mineralization retaining a small amount of ${ }^{15} \mathrm{~N}$ (panel D) during the brief exposure prior to washing the cells in the first few minutes of the experiment.

Clustering of the NanoSIMS images according to their distribution of processed ${ }^{15} \mathrm{~N} /\left({ }^{14} \mathrm{~N}+{ }^{15} \mathrm{~N}\right)$ ratio showed that the samples tended to cluster over the experimental time course into three different groups; "natural abundance" $\left({ }^{14} \mathrm{~N}\right)$ T0 controls, low ${ }^{15} \mathrm{~N}$ incorporation (NM_T0, M_T0, M_1d), and significant ${ }^{15} \mathrm{~N}$ incorporation (NM_1d, NM_2d, M_2d) (see Figure 6). The fact that controls for the natural abundance (NM_no incubation, M_no incubation) grouped separately from the T0 samples shows that even brief exposure to the ${ }^{15} \mathrm{~N}$ labeled medium during cell resuspension had an effect on the isotopic composition of the cells. The T0 samples were therefore used as the baseline of comparison for all later 


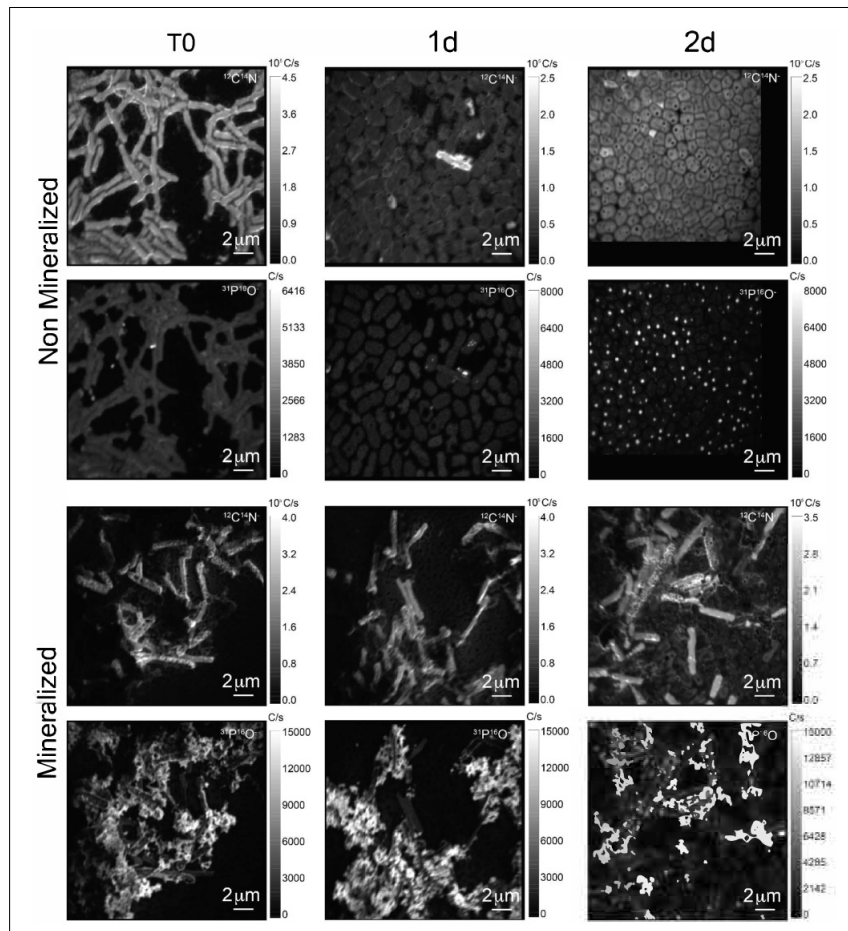

FIGURE $4 \mid{ }^{12} \mathrm{C}^{14} \mathrm{~N}$ - and ${ }^{31} \mathrm{P}^{16} \mathrm{O}$ - NanoSIMS images for both non-mineralized and mineralized cells over a time course of recovery after Fe-exposure.

time-points. The two remaining groups were composed of cells cultivated in ${ }^{15} \mathrm{~N}$-labeled medium, grouped by whether or not cell division had restarted. Low ${ }^{15} \mathrm{~N}$-incorporation samples (M_T0, NM_T0, M_1d) corresponded to cells not yet showing evidence of cell division, whereas samples with significant ${ }^{15} \mathrm{~N}$ incorporation (NM_1d, NM_2d, M_2d) showed clear evidence of active cell division when observed by SEM (see Figure 3) and measurements of optical density (see Supplementary Figure S3).

Variations between replicate images were minimal for all samples with the exception of both mineralized and non-mineralized 2 days samples, as seen in the heat map representation. The weighted distribution of subpopulations remained low for all samples prior to restart of cell division (see Figure 6 and Supplementary Figure S6, samples M_T0, M_1d, NM_T0). The increase in pixel subpopulations for samples showing signs of recovery and cell division (samples NM_1d, NM_2d, M_2d) reflects the heterogeneity of cell recovery. Heterogeneity in ${ }^{15} \mathrm{~N}$ incorporation was highest for cells immediately after S-layer shedding (M_2d samples), which is likely a reflection of natural variations in the capacity of Lysinibacillus sp. TchIII 20n38 cells to respond to stress.

\section{S-Layers Are Regenerated Within 2 Days of Fe-Mineral Encrustation}

Some cell-free mineralized S-layer shells were observed by SEM immediately after $16 \mathrm{~h}$ exposure to the Fe-rich solution (see
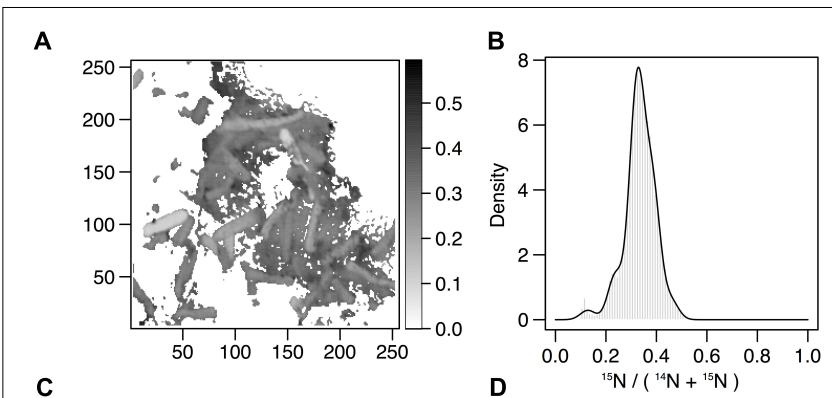

C
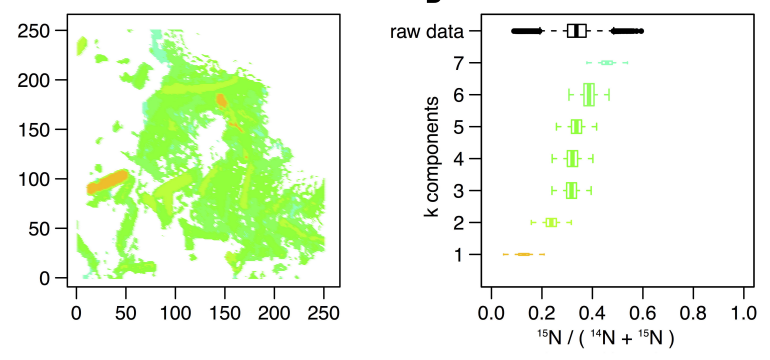

FIGURE 5 | Statistical analysis of ${ }^{15} \mathrm{~N} /\left({ }^{14} \mathrm{~N}+{ }^{15} \mathrm{~N}\right)$ NanoSIMS image for mineralized cells after 2 days of recovery (M_2d_rep16). (A) Processed ${ }^{15} \mathrm{~N} /\left({ }^{14} \mathrm{~N}+{ }^{15} \mathrm{~N}\right)$ ratio map. (B) Processed ${ }^{15} \mathrm{~N} /\left({ }^{14} \mathrm{~N}+{ }^{15} \mathrm{~N}\right)$ ratio histogram (gray bars) and probability density (dark line) estimated by Gaussian mixture modeling. (C) Map of the pixel subpopulations [see (D) for color code]. (D) Decomposition of the distribution of processed ${ }^{15} \mathrm{~N} /\left({ }^{14} \mathrm{~N}+{ }^{15} \mathrm{~N}\right)$ ratios (labeled "raw data") into four Gaussian components of unequal variance. The box boundaries indicate the first and third quartiles. The bold band inside the box corresponds to the median value. The horizontal dashed lines that extend from the box encompass the largest/smallest ratio values that fall within a distance of 1.5 times the box size from the nearest box hinge. If any, outliers are shown as individual points. Each component of the Gaussian mixture is represented by a random sample $(n=10000)$ from the corresponding normal distribution. The box heights represent the proportions of pixel subpopulations (i.e., the mixing proportions for the components). A unique color scale is used for all images, the subpopulation color depending on the estimated mean of the Gaussian component.

Figure 3). However, the morphology of the cells remained generally unchanged through 1 day of incubation in the defined medium. At 2 days of incubation in this medium, SEM observations clearly show a majority of non-mineralized cells alongside the remaining, cell-free, mineralized S-layer shells. Analyses of ${ }^{15} \mathrm{~N}$ uptake using NanoSIMS confirmed this timing, showing no significant ${ }^{15} \mathrm{~N}$ incorporation for mineralized samples prior to 2 days of recovery in labeled medium, compared to T0 control aliquots that were removed immediately after resuspension of cells in the labeled medium (see Figure 6). The S-layers of mineralized samples remained at a relatively steady ${ }^{15} \mathrm{~N} /\left({ }^{14} \mathrm{~N}+{ }^{15} \mathrm{~N}\right)$ ratio (see green regions in Supplementary Figure S6, mineralized samples) compared to the emerging cells, showing that mineralized S-layers did not incorporate ${ }^{15} \mathrm{~N}$ during the cell division processes giving rise to the emerging cells. This is coherent with S-layer shedding and complete regeneration. S-layer presence before and after mineralization and shedding was confirmed by SDS-PAGE and mass spectrometry (see Supplementary Figures S4, S5). 


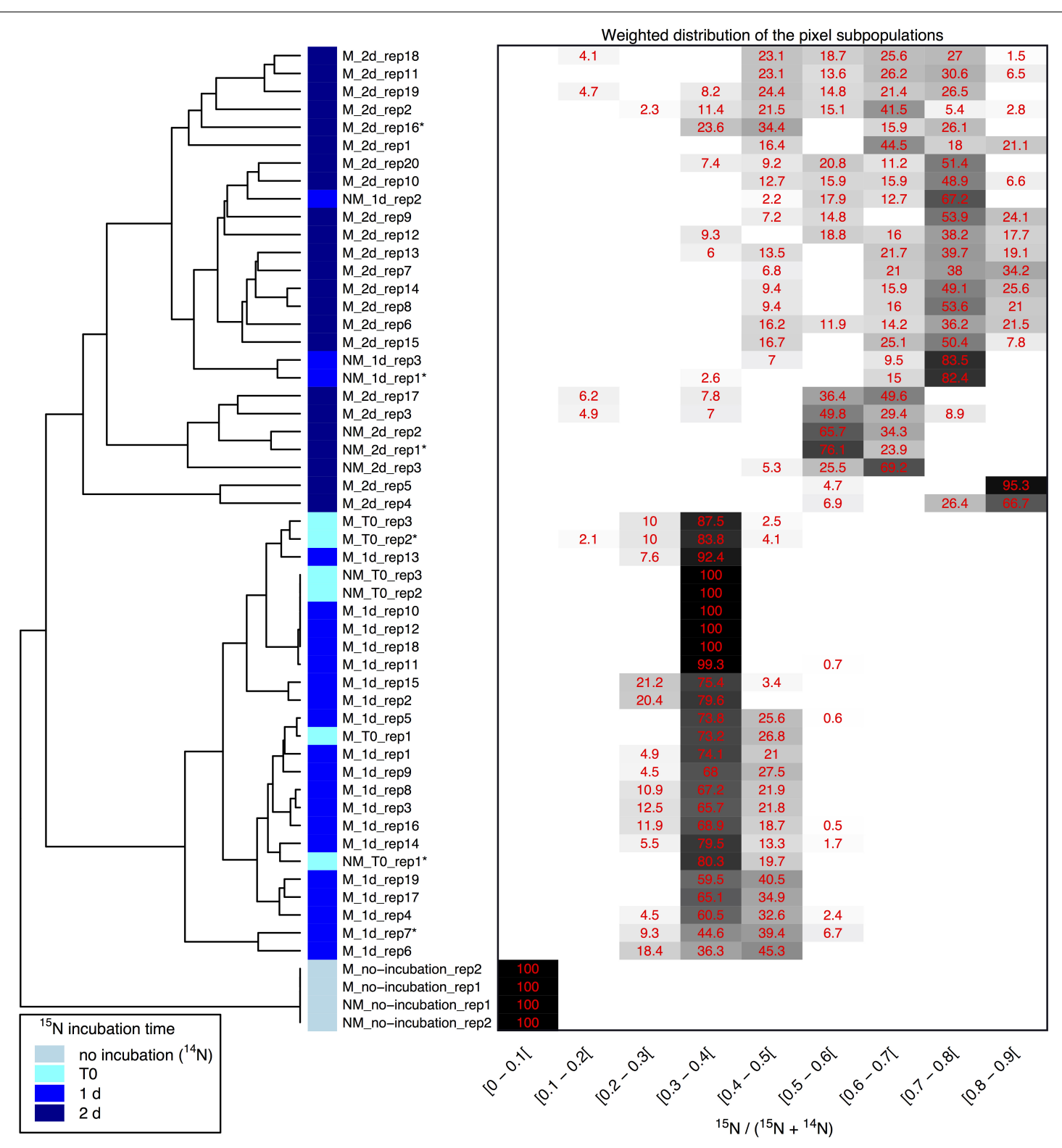

FIGURE 6 | Clustering of ${ }^{15} \mathrm{~N} /\left({ }^{14} \mathrm{~N}+{ }^{15} \mathrm{~N}\right)$ NanoSIMS images according to the distribution of pixel subpopulations. Each row of the heatmap (drawn on the right side of the figure) shows proportion (in \%) of the pixel subpopulations for a single NanoSIMS image, and columns show the ${ }^{15} \mathrm{~N} /\left({ }^{14} \mathrm{~N}+{ }^{15} \mathrm{~N}\right.$ ) ratio intervals. Each value corresponds to the sum of the mixing proportions for the Gaussian components whose mean falls in the given interval. Null proportions are hidden. Color scale ranges between white (0\%) and black (100\%). Each image is labeled according to the culture medium (either M or NM for Mineralized or Non-Mineralized, respectively), the ${ }^{15} \mathrm{~N}$ incubation time, and the replicate number (a NanoSIMS image numbering for a given sample). Each image is depicted by a color code according to the ${ }^{15} \mathrm{~N}$ incubation time of the sample (see color legend at bottom left). The heatmap rows are ordered according to the hierarchical clustering of images illustrated on the left side of the figure. Image labels ending with a star are further illustrated in Figure $\mathbf{5}$ and Supplementary Figure S6.

\section{DISCUSSION}

\section{Lysinibacillus sp. Tchlll 20n38 Is Highly Adapted for Survival Under Stress Conditions}

The bacterial isolate used in this study, Lysinibacillus sp. TchIII 20n38, is a metallotolerant gram-positive bacterium, possessing a cell envelope composed of the plasma membrane surrounded by a thick layer of peptidoglycan capped by an S-layer forming an ordered structure at the cell surface. This flexible cage-like structure is in direct contact with the surrounding environment, and thus provides the primary protective element against potentially toxic environmental concentrations of heavy metals or radionuclides. Such interactions between Lysinibacillus sp. cells and metals can lead to cell surface mineralization, biosorption, or intracellular bioaccumulation, depending on the depending on the types of metals present and physicochemical 
parameters such as $\mathrm{pH}$ (data not shown). Here, we show that Lysinibacillus sp. TchIII 20n38 has many adaptive mechanisms to the stresses induced by nutrient limitation and/or the presence of iron, as might be expected for a bacterium isolated from a radioactive waste disposal site. These included the accumulation and enlargement of intracellular polyphosphate granules and sporulation under phosphate-limiting conditions, cell size reduction, and morphology alterations from rodshaped to ovoid cells after metal stress, as well as reductions in biofilm after exposure to either iron or acidic $\mathrm{pH}$ and augmentation in biofilm after a return to neutral $\mathrm{pH}$ in the absence of additional iron input. Polyphosphate accumulation is a common mechanism used by bacteria, including Lysinibacillus sphaericus, in response to nutrient stress (depletion of amino acids), and prior to sporulation (Tocheva et al., 2013; Shi et al., 2015).

\section{S-Layer Shedding Mechanism in Lysinibacillus as a Response to Metal Stress}

S-Layers from a variety of prokaryotes are known to induce mineral formation. The S-layers of cyanobacteria are able to nucleate selenite and strontium (Schultze-Lam and Beveridge, 1994), while the S-layers of thermophilic archaea can form amorphous Fe-phosphate minerals in the quasi-periplasmic space between the S-layer and the underlying lipid membrane (Kish et al., 2016). Diverse Lysinibacillus sp. have been observed to precipitate minerals on their cell surfaces, including U-phosphates (Merroun et al., 2005; Mondani et al., 2011) and calcium carbonate (Kaur and Mukherjee, 2013). Here, we show that Lysinibacillus sp. TchIII 20n38 cells become encrusted with $\mathrm{Fe}$-minerals after exposure to high concentrations of iron under mildly acidic conditions. Mineral precipitation by the cell surfaces, including S-layers, prevent damages to cells including oxidative stress, enzyme deactivation, protein denaturation, and membrane disruption (Lemire et al., 2013). Iron precipitation nucleated by the S-layer proteins prevents an overproduction of free radicals in the cytosol due to Fenton chemistry.

While mineral formation on S-layers is known, the mechanisms for removing such barriers to exchange with the surrounding environment are not as well-understood. Mechanisms identified to date have described partial removal of cell envelope components after metal interactions, particularly membrane vesicle formation (McBroom and Kuehn, 2007; Shao et al., 2014; Kish et al., 2016). Partial shedding of S-layer fragments has also been observed, both for mineralized cyanobacterial S-layers (Schultze-Lam et al., 1992; Schultze-Lam and Beveridge, 1994) and non-mineralized S-layers for stationary phase bacteria likely as part of cell wall turnover (Luckevich and Beveridge, 1989). During the course of normal cell growth in the closely related Lysinibacillus sphaericus, bands of S-layer monomer insertion form on cell surfaces, and in the course of cell division new S-layer monomers are only inserted at the newly-formed the poles (Howard et al., 1982).

Here, we show that Lysinibacillus sp. cells were able to recover normal growth after mineral encrustation through a shedding of mineralized S-layers, followed by S-layer regeneration. To our knowledge, this is the first report of complete S-layer shedding and regeneration. S-layer shedding required an additional $24 \mathrm{~h}$ before cells returned to normal cell division compared to nonmineralized cells, as shown by the clustering of ${ }^{15} \mathrm{~N}$ uptake by 2 days mineralized cells with 1 day non-mineralized samples as measured by NanoSIMS over a time course after exposure to iron. Uptake of ${ }^{15} \mathrm{~N}$ also illustrated that despite extensive mineralization, cells retained active metabolism. The continued presence of shed, mineralized S-layers composed of ${ }^{14} \mathrm{~N}$-based proteins alongside cells bearing newly regenerated ${ }^{15} \mathrm{~N}$-bearing $\mathrm{S}$-layers resulted in the heterogeneity in ${ }^{15} \mathrm{~N}$-incorporation for the M_2d samples (see Figure 6). S-layer shedding activity was limited to cells in mid-exponential growth phase, providing an advantage over cells in stationary growth phase in Fe-rich conditions.

\section{Importance of S-Layer Regeneration in Metal Stress}

Now that the mechanism for S-layer shedding has been established for Lysinibacillus sp. TchIII 20n38, future work should explore the range of different metals that can be mineralized by S-layers, both in this bacterium and other S-layer bearing bacteria including both Gram-negative and Grampositive species. The high diversity of S-layer bearing bacterial species suggests that this mechanism could be widely used. Shedding of mineralized S-layers is less likely in the Archaea, given that for many species the S-layer is the sole component of their cell wall. Indeed, our previous work in the archaeon Sulfolobus acidocaldarius demonstrated that S-layer shedding was not observed; mineralized S-layers were rather partially sloughed off by the formation of membrane vesicles prior to cell encrustation (Kish et al., 2016).

The S-layer shedding and regeneration shown here after mineral encrustation may also inform new directions for S-layer use in in situ bioremediation. Current biotechnology applications of S-layers focus on in vitro applications such as the use of recombinant S-layer proteins with enhanced metal binding capacity (Pollmann and Matys, 2007), or as templates to nucleate the fabrication of metal nanoparticle biocatalysts (Creamer et al., 2007), or as bio-filters for bioremediation technologies (Pollmann et al., 2006). S-layer regeneration after mineralization may aid the development of new metal remediation strategies using metallotolerate soil bacteria native to soils contaminated by metals and radionuclides to reduce the bioavailability of toxic metals through mineralization.

\section{AUTHOR CONTRIBUTIONS}

AK and LR contributed to conception and design of the study. AC performed the experiments and wrote sections of the manuscript. LR performed the NanoSIMS measurements. CL and SZ performed the mass spectrometry analyses. ED performed the statistical analysis of NanoSIMS data. AK wrote the first draft of the manuscript. 
All authors contributed to manuscript revision, read and approved the submitted version.

\section{FUNDING}

This work was supported by the French National Program EC2CO-MicrobiEn, project "SkinDEEP, awarded to AK. The National NanoSIMS facility at the MNHN was established by funds from the CNRS, Région Ile de France, Ministère Délégué à l'Enseignement Supérieur et à la Recherche, and the MNHN. The SEM facility of the Institut de Minéralogie, Physique des Matériaux et Cosmochimie is supported by Région Ile de France grant SESAME 2006 NoI-07-593/R, INSUCNRS, INP-CNRS, Sorbonne Universités, and by the French National Research Agency (ANR) (Grant No. ANR-07-BLAN0124-01).

\section{REFERENCES}

Ahmed, I., Yokota, A., Yamazoe, A., and Fujiwara, T. (2007). Proposal of Lysinibacillus boronitolerans gen. nov. sp. nov., and transfer of Bacillus fusiformis to Lysinibacillus fusiformis comb. nov. and Bacillus sphaericus to Lysinibacillus sphaericus comb. nov. Int. J. Syst. Evol. Microbiol. 57, 1117-1125. doi:10.1099/ijs.0.63867-0

Benaglia, T., Chauveau, D., Hunter, D. R., and Young, D. (2009). mixtools: an RPackage for analyzing finite mixture models. J. Stat. Softw. 32, 1-29. doi: $10.18637 /$ jss.v032.i06

Chapon, V., Piette, L., Vesvres, M.-H., Coppin, F., Marrec, C. L., Christen, R., et al. (2012). Microbial diversity in contaminated soils along the T22 trench of the Chernobyl experimental platform. Appl. Geochem. 27, 1375-1383. doi: 10.1016/j.apgeochem.2011.08.011

Creamer, N. J., Mikheenko, I. P., Yong, P., Deplanche, K., Sanyahumbi, D., Wood, J., et al. (2007). Novel supported Pd hydrogenation bionanocatalyst for hybrid homogeneous/heterogeneous catalysis. Catal. Today 128, 80-87. doi: 10.1016/j.cattod.2007.04.014

Howard, L. V., Dalton, D. D., and McCoubrey, W. K. (1982). Expansion of the tetragonally arrayed cell wall protein layer during growth of Bacillus sphaericus. J. Bacteriol. 149, 748-757.

Kaur, D. N., and Mukherjee, A. (2013). Biomineralization of calcium carbonate polymorphs by the bacterial strains isolated from calcareous sites. J. Microbiol. Biotechnol. 23, 707-714. doi: 10.4014/jmb.1212. 11087

Kish, A., Miot, J., Lombard, C., Guigner, J.-M., Bernard, S., Zirah, S., et al. (2016). Preservation of archaeal surface layer structure during mineralization. Sci. Rep. 6:26152. doi: 10.1038/srep26152

Konhauser, K. O., Schultze-Lam, S., Ferris, F. G., Fyfe, W. S., Longstaffe, F. J., and Beveridge, T. J. (1994). Mineral precipitation by epilithic biofilms in the Speed river, Ontario, Canada. Appl. Environ. Microbiol. 60, 549-553.

Lemire, J. A., Harrison, J. J., and Turner, R. J. (2013). Antimicrobial activity of metals: mechanisms, molecular targets and applications. Nat. Rev. Microbiol. 11, 371-384. doi: 10.1038/nrmicro3028

Luckevich, M. D., and Beveridge, T. J. (1989). Characterization of a dynamic S layer on Bacillus thuringiensis. J. Bacteriol. 171, 6656-6667. doi: 10.1128/jb.171.12. 6656-6667.1989

McBroom, A. J., and Kuehn, M. J. (2007). Release of outer membrane vesicles by Gram-negative bacteria is a novel envelope stress response. Mol. Microbiol. 63, 545-558. doi: 10.1111/j.1365-2958.2006.05522.x

Merroun, M. L., Raff, J., Rossberg, A., Hennig, C., Reich, T., and SelenskaPobell, S. (2005). Complexation of uranium by cells and S-layer sheets of Bacillus sphaericus JG-A12. Appl. Environ. Microbiol. 71, 5532-5543. doi: 10. 1128/AEM.71.9.5532-5543.2005

\section{ACKNOWLEDGMENTS}

We gratefully acknowledge Virginie Chapon for giving us the strain used in this study, along with helpful discussions. We thank Adriana Gonzalez-Cano and Rémi Duhamel for assistance with NanoSIMS analyses, and Imène Esteve of the SEM facility of the Institut de Minéralogie, Physique des Matériaux et Cosmochimie for assistance with imaging, which was greatly appreciated. We also wish to thank Jennyfer Miot for productive discussions.

\section{SUPPLEMENTARY MATERIAL}

The Supplementary Material for this article can be found online at: https://www.frontiersin.org/articles/10.3389/fmicb. 2018.03210/full\#supplementary-material

Miot, J., Remusat, L., Duprat, E., Gonzalez, A., Pont, S., and Poinsot, M. (2015). Fe biomineralization mirrors individual metabolic activity in a nitrate-dependent Fe(II)-oxidizer. Front. Microbiol. 6:879. doi: 10.3389/fmicb.2015.00879

Mondani, L., Benzerara, K., Carrière, M., Christen, R., MamindyPajany, Y., Février, L., et al. (2011). Influence of uranium on bacterial communities: a comparison of natural uranium-rich soils with controls. PLoS One 6:e25771. doi:10.1371/journal.pone.002 5771

Phoenix, V. R., Adams, D. G., and Konhauser, K. O. (2000). Cyanobacterial viability during hydrothermal biomineralisation. Chem. Geol. 169, 329-338. doi: 10.1016/S0009-2541(00)00212-6

Pollmann, K., and Matys, S. (2007). Construction of an S-layer protein exhibiting modified self-assembling properties and enhanced metal binding capacities. Appl. Microbiol. Biotechnol. 75, 1079-1085. doi: 10.1007/s00253-0070937-5

Pollmann, K., Raff, J., Merroun, M., Fahmy, K., and Selenska-Pobell, S. (2006). Metal binding by bacteria from uranium mining waste piles and its technological applications. Biotechnol. Adv. 24, 58-68. doi: 10.1016/j. biotechadv.2005.06.002

R Core Team (2015). R: A Language and Environment for Statistical Computing. Vienna: R Foundation for Statistical Computing.

Rodriguez-Freire, L., Avasarala, S., Ali, A.-M. S., Agnew, D., Hoover, J. H., Artyushkova, K., et al. (2016). Post gold king mine spill investigation of metal stability in water and sediments of the animas river watershed. Environ. Sci. Technol. 50, 11539-11548. doi: 10.1021/acs.est.6b03092

Schultze-Lam, S., and Beveridge, T. J. (1994). Nucleation of celestite and strontianite on a cyanobacterial s-layer. Appl. Environ. Microbiol. 60, 447-453.

Schultze-Lam, S., Harauz, G., and Beveridge, T. J. (1992). Participation of a cyanobacterial S layer in fine-grain mineral formation. J. Bacteriol. 174, 79717981. doi: 10.1128/jb.174.24.7971-7981.1992

Scrucca, L., Fop, M., Murphy, T. B., and Raftery, A. E. (2016). mclust 5: clustering, classification and density estimation using gaussian finite mixture models. $R J$. 8, 289-317.

Shao, P. P., Comolli, L. R., and Bernier-Latmani, R. (2014). Membrane vesicles as a novel strategy for shedding encrusted cell surfaces. Minerals 4, 74-88. doi: $10.3390 / \min 4010074$

Shi, T., Ge, Y., Zhao, N., Hu, X., and Yuan, Z. (2015). Polyphosphate kinase of Lysinibacillus sphaericus and its effects on accumulation of polyphosphate and bacterial growth. Microbiol. Res. 172, 41-47. doi: 10.1016/j.micres.2014.12.002

Sleytr, U. B., Egelseer, E. M., Ilk, N., Pum, D., and Schuster, B. (2007). S-Layers as a basic building block in a molecular construction kit. FEBS J. 274, 323-334. doi: 10.1111/j.1742-4658.2006.05606.x

Sleytr, U. B., Schuster, B., Egelseer, E. M., and Pum, D. (2014). S-layers: principles and applications. FEMS Microbiol. Rev. 38, 823-864. doi: 10.1111/1574-6976. 12063 
Sleytr, U. B., Schuster, B., Egelseer, E. M., Pum, D., Horejs, C. M., Tscheliessnig, R., et al. (2011). Nanobiotechnology with S-layer proteins as building blocks. Prog. Mol. Biol. Transl. Sci. 103, 277-352. doi: 10.1016/B978-0-12-415906-8. 00003-0

Thomen, A., Robert, F., and Remusat, L. (2014). Determination of the nitrogen abundance in organic materials by NanoSIMS quantitative imaging. J. Anal. At. Spectrom. 29, 512-519. doi: 10.1039/c3ja50313e

Tocheva, E. I., Dekas, A. E., McGlynn, S. E., Morris, D., Orphan, V. J., and Jensen, G. J. (2013). Polyphosphate storage during sporulation in the gram-negative bacterium Acetonema longum. J. Bacteriol. 195, 3940-3946. doi: 10.1128/JB. 00712-13
Conflict of Interest Statement: The authors declare that the research was conducted in the absence of any commercial or financial relationships that could be construed as a potential conflict of interest.

Copyright $\odot 2019$ Chandramohan, Duprat, Remusat, Zirah, Lombard and Kish. This is an open-access article distributed under the terms of the Creative Commons Attribution License (CC BY). The use, distribution or reproduction in other forums is permitted, provided the original author(s) and the copyright owner(s) are credited and that the original publication in this journal is cited, in accordance with accepted academic practice. No use, distribution or reproduction is permitted which does not comply with these terms. 